\title{
Kinship care or upbringing by relatives? The need for 'new' understandings in research
}

\section{Slektsfosterhjem eller oppvekst hos slekt? Behovet for 'nye' forståelser i forskning}

\author{
Jeanette Skoglund \& Renee Thørnblad
}

\begin{abstract}
This article addresses knowledge production on formal kinship foster care. In spite of growing interest in this phenomenon, little attention has been paid to how kinship care should be understood in research - as a service under child protective services or as upbringing by relatives. Each of these understandings leads to different research questions and creates guidelines for what falls into or outwith the focus of research. In kinship care research, this phenomenon has primarily been studied as a service. Research that seeks to evaluate the effect of kinship care compared to non-kinship care is used as a case to discuss the implications for the type of knowledge that researchers produce. While we acknowledge the importance of this research, we demonstrate the many challenges it involves and why this should not be the primary focus in kinship care research. On the background of these limitations, we argue in favour of approaching kinship care as upbringing by relatives - as ways in which family life can be organised and structured. This can lead to relevant knowledge that will enable us to obtain a better understanding of what kinship care is and involves.
\end{abstract}

\section{Sammendrag}

Denne artikkelen retter søkelys mot kunnskapsproduksjonen om slektsfosterhjem. Til tross for en $\varnothing \mathrm{kt}$ interesse for dette fenomenet blant forskere i en rekke land har spørsmålet om hvordan vi skal forstå slektsfosterhjem uteblitt i forskning: som barneverntiltak eller som oppvekst i slekt. Hvilke forståelse man velger gir retningslinjer for spørsmålene som stilles og for hva som faller innenfor og utenfor forskningens fokus. Flertallet av studier som retter seg mot slektsfosterhjem har tilnærmet seg fenomenet forstått som tiltak. I artikkelen spør vi hvilke implikasjoner dette ensidige fokuset har for kunnskapen som produseres. Effektstudier som søker å evaluere slektsfosterhjem brukes som utgangspunkt for diskusjon. I artikkelen løfter vi frem en rekke utfordringer ved denne forskningen og viser hvorfor dette ikke bør være det primære fokuset i forskning knyttet til slektsfosterhjem. På bakgrunn av begrensningene som løftes frem argumenterer vi for forskning som tilnærmer seg slektsfosterhjem som oppvekst i slekt - som en av flere ulike måter familieliv kan strukturers og organiseres. Dette kan gi relevant kunnskap som kan gi oss en bedre forståelse av hva slektsfosterhjem er og involverer.

KEYWORDS: Upbringing by relatives, kinship foster care, family practices, knowledge production, effect studies

NØKKELORD: Oppvekst i slekt, familiepraksiser, kunnskapsproduksjon, effektstudier 
'Like many features of a landscape, knowledge looks different from different angles. Approach it from an unexpected route, glimpse it from an unusual vantage point, and at first it may not be recognizable.' (Bloor, 1976, p. 144)

Evidence-based thinking has influenced a wide range of sectors in the past few years, from health care to management. Briefly, the intention with evidence, understood as a systematic approach to policy and practice, is to increase transparency by the use of rigorous, standardised and up-to-date evaluations (Gray, Plath, \& Webb, 2009, p. xiv). Social work practice and research are no exceptions to this influence, as it has gained much support amongst politicians and bureaucrats internationally.

The adoption of evidence-based thinking and practice (EBP) has been a much-debated topic among social work researchers in many countries for several years. The arguments in favour of embracing EBP in social work practice and research has ranged from the ethical and ideological to the highly practical (Boaz \& Blewett, 2010, p. 38). On the other hand, constructivist and qualitatively oriented researchers have challenged this dominant positivist paradigm in social work research, by arguing that positivism does not have the only claim to knowledge (Pease, 2010, p. 99). These critical voices have been important, as they have showed the importance of embracing a wider notion of knowledge, thus creating space for a range of research approaches in social work research.

One area in which these critical voices have been sparse, however, is the research field of formal kinship foster care, ${ }^{1}$ hereby referred to as kinship care. This article aims to encourage researchers to engage in a critical knowledge discussion of what future research should focus on and to open up for a diversity of philosophical research traditions and research methodologies in the study of kinship care.

\footnotetext{
${ }^{1}$ Kinship foster care is also known as family and friends care in the United Kingdom and kith and kin care in Australia (Winokur, Holtan, \& Batchelder, 2014, p. 3). In Norway, kinship care is known as slektsfosterhjem.
} 
To contribute to such a discussion, we seek to stimulate reflection on the implications of what understanding we base kinship care on in research. As an analytical point of departure, we make a distinction between two main ways of understanding kinship care: as a service within child protective services and as upbringing by relatives - as ways in which family life can be structured and organised in different cultural and social environments. While the first understanding represents a positivist epistemology, the latter is based on an interpretive epistemology. Whichever of the two that we choose in research will offer guidelines for the type of questions asked (and not), and what falls within and outwith the focus of our research. If we understand kinship care predominantly as a service within child protective services, this directs the researcher towards topics such as stability and breakdown, risk, effects and comparisons of kinship care with other services. Understood as upbringing by relatives, on the other hand, it opens up questions regarding how family, childhood and parenthood are negotiated and lived among woman and men, boys and girls. From this perspective, kinship care is not studied as a thing-like object, but as a context in which family life is practised. This construction builds on contemporary understandings of family found within the sociology of family life and makes theoretical and empirical studies from this tradition relevant to the study of kinship care. In other words, how we understand kinship care has major implications for what type of knowledge researchers produce.

With few exceptions represented in the research literature (e.g. Holtan, 2008; Thørnblad \& Holtan, 2011b), upbringing by relatives has primarily been studied as a service (e.g. Andersen \& Fallesen, 2015; Chamberlain, Price, Reid, Landsverk, Fisher, \& Stoolmiller, 2006; Cuddeback, 2004; Font, 2015; Winokur et al., 2014). Here, we use evaluative effect studies as a means of exploring the fruitfulness of this understanding in research. By demonstrating its limitations, we attempt first to show that this often reductionist approach can produce misleading knowledge regarding what kinship care is and involves for the woman and men, 
boys and girls we find behind this category. Secondly, we seek to show what type of knowledge we can gain from shifting our understanding of kinship care in research from service to upbringing by relatives. This, we argue, will lead to a different and much needed type of knowledge, which is necessary if we are to obtain a better understanding of kinship care.

\section{Kinship Care: Under the Gaze of Social Work Research}

Upbringing by relatives is a long-standing tradition in many cultures. Kinship care, as category and a service, however, is a relatively new construction within child protective services. Researchers in several countries have documented a general skepticism in social workers' attitudes to kinship care, especially to grandparents who did not succeed in raising the child's parent (Egelund, 1997; Havik \& Backe-Hansen, 1998; Hessle \& Vinnerljung, 1999; Linderot, 2006; Sinclair, Baker, Lee, \& Gibbs, 2007). However, in Western Europe, the United States, New Zealand and Australia, there has been a shift in child protective services that encourage the use of kinship care when children cannot live with their birth parents. As a result, many countries have witnessed an increased use of kinship care placements in the course of the past 25 years.

There are several reasons for this transition. Although its causes differ from country to country, they include a rising need for out-of-home care, a shortage of foster care homes, concerns about research showing poor outcomes for young adults leaving foster care, economic factors and a growing emphasis on cultural belonging (Berrick, 1998; Berrick, Barth, \& Needell, 1994; Gibbs \& Müller, 2000; Thørnblad, 2009).

As kinship care has become a significant part of child protective services, the research field of kinship care has emerged. The first research contributions came from the American context in the 1990s, soon followed by the first Nordic study conducted by Vinnerljung in 
1993. In the UK, the emergence of kinship care research can be traced to the pioneering work of Broad and others (Broad, 2001; Broad, Hayes, \& Rushforth, 2001; Flynn, 2002; Pitcher, 1999).

While kinship care is a relatively recent phenomenon in social work research, upbringing by relatives, childhood, parenthood and grandparents' involvement in child rearing have all been areas of interest to sociologists, anthropologists and historians for decades. Within these fields, family life and kinship have been studied in relation to a wider exploration of change, stability and diversity of family life and kinship practices within different social and cultural contexts (e.g. Cheal, 2002; Gullestad \& Segalen, 1997; Morgan, 1996). In kinship care research however, these traditions have been paid little attention.

\subsection{Kinship care versus non-kinship care}

Becoming a foster care option incorporated into child protective services has involved several changes, both for the families involved and child protective services. However, this transition has also contributed to a new understanding of an old phenomenon: from a private family solution to a service under child protective services inscribed with an institutional definition and goals.

With the growing importance of kinship care placements, politicians, bureaucrats, social workers and researchers have raised questions about the 'quality' of kinship care, and whether placing children with relatives is better, worse or about the same as non-kinship care. Proponents of kinship care have argued that preexisting bonds between child and relative can facilitate positive attachments and reduce the trauma children may experience when placed with strangers. Furthermore, growing up with kin can reinforce children's sense of identity and self-esteem, which flows from their family history and culture (Dubowitz, 1994; Iglehart, 1994; Knudsen \& Egelund, 2011). On the other hand, those more critical to kinship care 
placements have raised concerns about the ability of kinship caregivers to protect children from continued neglect and abuse by birth parents, the quality of their care and in general, the outcomes for the children involved (Bartholet, 1999; Pierce, 1999).

During the past few years, much research on kinship care has attempted to contribute to this debate by evaluating the 'effects' of kinship care placements compared to non-kinship care placements (Backe-Hansen, Egelund, \& Havik, 2010; Brown \& Sen, 2014; Cuddeback, 2004). Most of this research has shown positive outcomes for children growing up with kin caregivers (Winokur, Holtan, \& Batchelder, 2014). In that respect, it has played a key role as a counterweight to negative perceptions of kinship care. Nevertheless, researchers still disagree on which out-of-home placement option is preferable. As such, the effect of kinship care compared to non-kinship care continues to be one of the central issues guiding the knowledge production on kinship care (e.g. Andersen \& Fallesen, 2015; Bell \& Romano, 2015; Font, 2014, 2015; O'Brien, 2012; Winokur et al., 2014).

At first sight, the ongoing focus on evaluating the effect of kinship care versus foster care may appear to be self-evident: when children cannot live at home, we need to know which placement option is the better. However, we argue that these questions and problems only occur when we approach kinship care as a service provided by child protective services. If we uncritically adopt this understanding, we cannot escape the very logic and legislation of child protective services - the categories, language and problems that appear to us as selfevident. Following Bourdieu and Wacquant (1992), we can say that this is because this understanding represents the preconstructed understanding of kinship care. As a result, as soon as we say 'kinship care', questions regarding the results or effects of growing up with kin automatically appear while other issues disappear. This may to a certain extent explain why the sociology of family life has been paid so little attention in the study of kinship care: 
under the gaze of social work research, this phenomenon has been studied more as a technology (Ulvik, 2009) and less as family.

\section{A Critique beyond the fields represented challenges}

Researchers' preoccupation with the effect of kinship care compared to non-kinship care is reflected in the range of outcome studies conducted the past years. Here, researchers attempt to gain knowledge on the ability of each type of care to meet the three recognized goals of child protection services: safety, permanency, and well-being (Bell \& Romano, 2015; Cuddeback, 2004; Winokur et al., 2014; Wu, White, \& Coleman, 2015). As Winokur et al. (2014) have shown, this is no longer a trend only in American research, but in many other countries where kinship care has become significant. Despite the hegemonic position given to effect studies above other approaches, many positivist-oriented researchers have identified a number of methodological weaknesses in these studies (e.g., Cuddeback, 2004; Gleeson \& Hairston, 1999; Nixon, 2007; O'Brien, 2012). The constraints and challenges described in the literature have particularly concerned the lack of representative studies and adequate control groups. Many have pointed to the need for longitudinal studies in addition to more standardised measures to permit greater comparability of results. These examples are illustrations of this research field's own 'represented challenges' and it is through them that we see the limits of its own critical awareness. We can say that instead of critically addressing the question of what type of knowledge we gain from these studies, the focus has been on how to overcome methodological obstacles, providing more 'robust evidence'. This is what Ulvik (2009) calls internal paradigm method criticism - wanting more of the same.

Recent studies of the effect of kinship care are good examples to illustrate how these obstacles contributes to a continued legitimisation of this focus. While meta-analyses have been published to overcome the lack of representative studies in the field (e.g., Bell \& 
Romano, 2015; Cuddeback, 2004; Winokur et al., 2014), recent work has argued that the studies represented in the meta-analysis does not truly reflect the effects of kinship care. According to Font (2014), they do not take into account the favourable starting point of children in kinship care. Referring to previous American studies, she highlights that these children are younger and less likely to suffer from disabilities or health problems. If these characteristics are not taken into account, the results will automatically show better outcomes for children and young people who grow up with kin. In line with this argument, Andersen and Fallesen (2015, p. 70) argue that earlier research on the effects of kinship care is useful as descriptive evidence; 'but has limited use if we aim at giving policy recommendations on whether or not to use kinship care.'

When they emphasise the methodological limitations of previous effect studies, these researchers are not only indicating that their research is a step closer to the truth, but that this truth is possible to find. Implicit in this approach is the understanding that there is a reality out there to be studied, captured and understood (Guba, 1990, p. 22). Within this positivist position the object of research does not appear to be constructed at all. However, to not consciously construct is still to construct, because it 'amounts to recording - and thus to ratifying- something already constructed' (Bourdieu \& Wacquant, 1992, p. 236). This means that effect studies do not develop new categories, theories and ways of understanding kinship care. Rather, they end up by documenting which social problems are taken to be legitimate when studied under the gaze of social work research.

\subsection{Transferability to practice}

The relevance of research that compare the effects of kinship care to non-kinship care rarely needs further explanation. Additionally, many politicians, bureaucrats and practitioners wish for simple, comparable and accurate measures, which can be used for policy 
development and in decision-making processes. From this perspective, effect studies are the very definition of what constitutes ‘useful research' (Staunæs \& Søndergaard, 2005, p. 51). However, as McCarthy and Edwards (2011, p. 68) highlight, we cannot transfer findings from effect studies to individual children. This means that a caseworker who has decided to initiate an out-of-home placement cannot use this research to determine what the best option for that particular child is.

In his critique of the evidence based practice movement, Frost (2002, p. 43) makes a similar point in his discussion of the problem of applying evidence to practice. Using kinship care research as an example, Frost argues that even though we accept that children in kinship care generally have better outcomes than children in foster care, it does not mean that any particular placement in kinship care will be successful. According to Frost, all we can say is that a given child is likely to do better if placed with a relative, but the research evidence cannot be determinate in a given situation. In other words, knowledge produced from effect studies does not easily transfer to relevant knowledge for social work practice.

\subsection{The 'thingliness' of kinship care and generalisation of context-dependent research}

\section{findings}

The list of challenges involved when seeking to evaluate the effect of kinship care compared to non-kinship care is long. One of the most obvious challenges is that the experiences of members of the families within these categories are rarely included. Studying 'effects' distinct from the people who live in such families is a challenge, because how children and adolescents understand and give meaning to their life situation is important for how they experience the 'outcome' of the placement.

Furthermore, this type of research often fails to take into account the diversity of the relationships and family compositions we can find within the categories of kinship care and 
non-kinship care. Instead of acknowledging this diversity, kinship care and non-kinship care are treated as homogeneous categories, which can be measured and compared. Moreover, kinship care involves not only caregivers and children, but is different in relation to socioeconomic status, age, support from child protective services and so on. Some children grow up with grandmothers, others with aunts and uncles. Similarly, children may have lived with grandparents or other relatives their whole lives, prior to this becoming an official kinship care placement. Further ways in which these families differ are the relationships that make up these families. Holtan's (2008) study exemplifies this. Using data from her mixed method study, Holtan developed five archetypal constructions based on how caregivers, birth parents and children experienced their family relationships.

While acknowledgement of family diversity is one thing, another is recognising the very social and cultural contexts within which these families are practised. Like kinship care, childhood, parenting and family are not static categories, but vary from country to country, within nations and cultures and changes with time. A grandmother raising a grandchild might be two very different projects in the US and in Norway. Similarly, what it means to raise a grandchild in contemporary Norway today is not necessarily the same thing as it was only few decades ago.

The problem of ignoring social and cultural contexts in research is intensified by studies that attempt to generalise effects of kinship care across national borders and continents. While such a mission obviously need to be the subject of meta-analyses, and literature reviews, we can also find examples of this in single-population studies. In their study of the effects of kinship care on foster care disruption rates in Denmark, Andersen and Fallesen (2015, p. 69) argue that their findings can be generalised to other Western countries. Despite the generous Danish welfare state and the extensive social safety net, they claim that kinship care in Denmark is 'very similar to kinship care in other Western countries'. Their 
argument is based on the many quantitative studies showing that kinship caregivers in Denmark, as in many other Western countries, tend to have fewer socio-economic resources than other caregivers, and are likely to live in troubled neighbourhoods. Furthermore, compared to caregivers in regular foster care, caregivers in kinship care receive less support from child protective services. Finally, kinship care takes place in a familiar environment, which can secure a degree of continuity in the lives of the children involved. As Andersen and Fallesen show, we can find many similar characteristics throughout the kinship care category in many countries. However, what they do not take into account are the different social and cultural conditions we can find in Denmark and in the U.S. Furthermore, as showed by Berrick, Peckover, Pösö, and Skivenes (2015), Nordic countries and the US have different child protective services and policies. This means that generalisations in social work research are difficult to make, and that the value of transferring context-dependent research findings from one country to another is limited.

To sum up, our critique moves beyond represented challenges in effect studies towards a paradigm approaching reality as stable set of delineated phenomena - or what can be called a reality ascertainable optic (Staunæs \& Søndergaard, 2005, p. 51). Social 'reality' is not fixed, but consists of complex processes. If kinship care is stripped of these complexities, the experiences of the members involved, the variety of family forms and relationships within the kinship care category and the social and cultural context within which family is practised, we are not only reducing a complex phenomenon to factors - but kinship care as a category becomes a 'thing'. 


\section{Reflexive empirical research}

Transferring ideals from the natural sciences into the study of social phenomenona is difficult. However, when we argue in favour of new approaches in the study of kinship care, we are not against positivist quantitative studies per se, but rather in favour of more 'reflexive empirical research', which means that:

' (...) serious attention is paid to the way different kinds of linguistic, social, political and theoretical elements are woven together in the process of knowledge development, during which empirical material is constructed, interpreted and written' (Alvesson \& Sköldberg, 2009, p. 9).

A reflexive mode involves a scepticism to how previously well-established understandings and categories influence the questions we ask, how we perform our research, and how we write it up. Furthermore, we need to remember that children who grow up with their relatives and the relatives who care for these children have been subject to the category kinship care, from which they cannot escape. More grounded research, based on actual understandings and experiences of children and young people growing up in kinship care, has shown that many do not identify themselves as foster children growing up in foster care. In a longitudinal study of kinship care, Thørnblad and Holtan (2011a) explored young adults' experiences of growing up in kinship care. One of their major findings was that the participants emphasised normality and kinship bonds when talking about family relationships. While Thørnblad \& Holtan's study took place in a Norwegian context, similar findings have been found in Denmark (Egelund, Jakobsen, \& Steen, 2010) and Scotland (Burgess, Rossvoll, Wallace, \& Daniel, 2010). As Thørnblad \& Holtan emphasise, an upbringing among relatives can be very different from traditional foster care placements, as it is often based on already established social and emotional bonds. Based on their findings, the authors question the 
fruitfulness of similar models and formal frameworks for these families as those established for other foster homes.

What these studies illustrate is that many children and adolescents growing up with relatives do not identify themselves as objects of a foster care service - they do not talk about themselves as foster children and their kin as foster parents. They do not use words such as service or effects. Rather, they talk about growing up with grandmother or their aunt and uncle, about what they do together, about their birth parents and their siblings. In other words, they talk about different childhoods lived in different families where relationships are negotiated and family is practised in everyday life.

As researchers, we have the power to influence the meaning of the categories we study. How we do this should always reflect the meaning of the people who fall under these categories. Hence, the unintended consequence of approaching kinship care as a service in research is that we end up providing misleading knowledge not only about what kinship care is, but also what it involves.

\subsection{Upbringing by relatives: the alternative understanding}

The alternative construction we argue in favour of understands kinship care as upbringing by relatives. In short, this involves approaching kinship care as ways in which family life can be organised and structured in all its diversity and complexity. When emphasising such a shift, we are not arguing that one should give up the word kinship care per se. Rather, we seek to contribute with a tool that can challenge the preconstructed understanding of kinship care.

When studied as family, empirical and theoretical contributions from the study of family life becomes relevant. Thus, if we are to understand what type of knowledge we can gain from this understanding we also need to look more closely at some of the key theoretical 
developments within this research field. However, before doing so, it is important to emphasise that the study of family life occupies a wide range of research traditions, including anthropology, history, psychology and legal studies, to name but a few. Between, and within, each of these disciplines, families are understood and explored in different ways. The primary discipline that creates our perspective here is sociology.

One of the key aims of the sociology of family life has been to explore the relationship between societal changes and family structure and practices (Smart, 2007). In recent decades, expectations, commitments and practices have changed significantly in intimate relationships and family life, resulting in single-parent families, post-divorce and 'blended families', samesex unions, friends as families, living apart together (LAT), cohabiting couples and other relationships and living arrangements living side by side.

Within the field of sociology of family life, there has been widespread agreement that we need concepts sensitive enough to be capable of identifying and explaining the diversity and complexity of today’s family life (Chambers, 2012). David Morgan's (1996, 2011) notion of 'family practices' has emerged as a fruitful concept in that respect. Developing the concept as a means of capturing the flux and fluidity of family life, Morgan has attempted to divert researchers' attention from understanding 'family' as a static category determined by legal bonds, blood ties or residence: ' there is no such thing as 'The Family' '(Morgan, 2011, p. 3). Rather, families are constantly undergoing change, both in historical time and in the individual family moving through that time. From this constructivist perspective, families are actively created by its members; rather than understanding family as something people are, the focus is on what people 'do'.

The move from treating family as a 'thing' towards an emphasis on fluidity has emerged as a fruitful approach in many empirical studies of family life, from the explorations of post-separation parenting arrangements (Smart \& Neale, 1999) to analysis of same-sex 
intimacies (Weeks, Heaphy, \& Donovan, 2001). We believe that the concept of practices, along with empirical writing and other theoretical contributions from the field of sociology of family life, is also fruitful for the study of kinship care.

Many families who fall under the category of kinship foster care have divided parenthoods where the kin caregiver raising the child is responsible for everyday care while the birthparents have the parental responsibility. Just as in families in which the parents are divorced and live in separate households, the different parties need to negotiate how this should be done in the process of family construction. As Holtan (2008) showed, the negotiations of family relationships leave room for different types of collaborations between birth parents and caregivers. Holtan argues that if the parties have friendly relationships among themselves and experience a sense of solidarity and community, this will have a positive impact on the social integration of the child. What Holtans' study showed is that when understood as constituted through practice we can explore different ways of 'doing' kinship care. Future exploration of family practices in these families can provide important insights into how different family practices give different childhood experiences and relationships between children and their birth parents, and children and their caregivers. Furthermore, it enables us to explore kinship care in relation to different family forms. As we have pointed out, knowledge production on kinship care has predominantly evolved around comparing kinship care to non-kinship foster care. Some researchers have argued that since kinship care families in many ways are so fundamentally different from other foster care arrangements, a direct comparison might not be as fruitful (e.g. Flynn, 2002; Nixon, 2007). However, when constructed as a service in research, it is difficult to envisage alternative ways of approaching this topic. Constructed as upbringing by relatives - as families, not as a service - gives us this opportunity. The concept of family practices contrasts to earlier sociological understandings, where families were studied as an institution in society (e.g. Parsons \& Bales, 
1955), and builds on the individualisation thesis (Beck \& Beck-Gernsheim, 1995; Giddens, 1992). Briefly, these concepts refer to the decreased regulation of traditional structures and the increase of reflexivity regarding how social life is lived. However, many of the empirical studies have also challenged these concepts, displaying a continuing focus on commitment and connectedness within the diversity of family forms (Smart \& Neale, 1999; Williams, 2004). We believe that theoretical and empirical concepts on the relationship between new possibilities and cultural constrains are relevant in explorations of families within the category kinship care. An example is in analysis of family contact. Compared to children in nonkinship care, children in kinship care have more contact with birthparents and other family members. One possibility would be to explore how adolescents and young adults relate to their birth parents when they themselves have the opportunity to "choose" what this relationship is going to involve. Such knowledge can give important insights into an undeveloped area in kinship care research (Kiraly \& Humphreys, 2013), and can contribute with insights into contemporary debates over individualisation and what it means for family life.

The above examples offer insights into what type of knowledge we can gain from approaching kinship care as upbringing by relatives. In brief, this construction allows us to ask new questions in research and gives access to theoretical and empirical contributions from fields outside social work research. However, the relevance of changing approach is not restricted to research. The social worker who takes on this perspective acknowledges the diversity of family forms and relationships that can be found within the category kinship care. The concept of family practices can be especially helpful in this regard, as it gives knowledge about how family is negotiated and lived. As we showed above with Holtan's study, the relationship between caregivers and birthparents is essential to understand what kinship care 
entails. With that said, it is important not to reduce family life in kinship care to involve only children, birth parents and caregivers - family can also involve friends and extended family. Understanding how family life is practised and who is included in these projects is important for many reasons. One of the most obvious is that child welfare measures cannot be adapted to fit all families, but must be accommodated to meet the different needs found in different families. However, it is also a way of giving people power to define what kinship care is to them. For some children, this means growing up with grandma, for others it can mean growing up with an aunt and uncle whom they call mum and dad. From these perspectives, the language used in child protective services is not transferrable; the word kinship care might not even be recognisable. In other words, approaching kinship care as upbringing by relatives involves acknowledging the perspective of the people involved - both in social work practice and in research.

\section{Conclusions: the need for new understandings in kinship care research}

In this article, we have distinguished between two main ways of understanding kinship foster care in research - as a service and as upbringing by relatives. While research based on the first understanding refers a positivist epistemology, the latter is based on an interpretive epistemology. We believe that both understandings can offer important insights into kinship care. However, as researchers we need to understand and acknowledge that the understanding we adopt in research will guide and limit our research focus. Kinship care is a socially constructed category, inscribed with meaning and goals based on the logic and legislation of child protective services. Following this preconstructed understanding will lead to one type of knowledge. What is challenging, however, is when this perspective becomes the primary lens through which we see kinship care. 
Underlying the category of kinship care, we find women and men, boys and girls who in their own ways practise childhoods, parenting and family life. These areas have been paid little attention in research. The sociology of family life can contribute empirical and theoretical concepts to help us explore these areas. Most importantly, these perspectives enable us to break with existing language and problems represented in child protective services, enabling us to ask new questions. This can lead to important knowledge that will enable us to better understand what kinship care involves for the persons we find within this category. 


\section{References}

Alvesson, M., \& Sköldberg, K. (2009). Reflexive methodology: New vistas for qualitative research. London: Sage.

Andersen, S. H., \& Fallesen, P. (2015). Family matters? The effect of kinship care on foster care disruption rates. Child Abuse \& Neglect, 48, 68-79. doi:10.1016/j.chiabu.2015.06.005

Backe-Hansen, E., Egelund, T., \& Havik, T. (2010). Barn og unge i fosterhjem - en kunnskapsstatus [Children and youth in foster care - A status of knowledge]. Oslo: NOVA.

Bartholet, E. (1999). Nobody's children: Abuse and neglect, foster drift, and the adoption alternative. Boston, MA: Beacon Press.

Beck, U., \& Beck-Gernsheim, E. (1995). The normal chaos of love. Cambridge, England: Polity press.

Bell, T., \& Romano, E. (2015). Permanency and Safety Among Children in Foster Family and Kinship Care: A Scoping Review. Trauma, Violence, \& Abuse, 1-19. doi:10.1177/1524838015611673

Berrick, J. D. (1998). When children cannot remain home: Foster family care and kinship care. The future of children, 8(1), 72-87.

Berrick, J. D., Barth, R. P., \& Needell, B. (1994). A comparison of kinship foster homes and foster family homes: Implications for kinship foster care as family preservation. Children and Youth Services Review, 16(1), 33-63.

Berrick, J. D., Peckover, S., Pösö, T., \& Skivenes, M. (2015). The formalized framework for decisionmaking in child protection care orders: A cross-country analysis. Journal of European Social Policy, 25(4), 366-378. doi: 10.1177/0958928715594540

Bloor, D. (1976). Knowledge and social imagery. London: Routledge \& Kegan Paul.

Boaz, A., \& Blewett, J. (2010). Providing objective, impartial evidence for decision making and public accountability. In I. Shaw, K. Briar-Lawson, J. Orme, \& R. Ruckdeschel (Eds.). The Sage handbook of social work research (pp. 37-48). London: SAGE Publications.

Bourdieu, P., \& Wacquant, L. J. (1992). An invitation to reflexive sociology. Chicago, IL: Chicago University Press.

Broad, B. (2001). Kinship Care: the placement choice for children and young people. Lyme Regis: Russell House.

Broad, B., Hayes, R., \& Rushforth, C. (2001). Kith and Kin: Kinship Care for Vulnerable Young People. London: National Children's Bureau

Brown, L., \& Sen, R. (2014). Improving Outcomes for Looked after Children: A Critical Analysis of Kinship Care. Practice: Social Work in Action 26(3), 161-180. doi:10.1080/09503153.2014.914163

Burgess, C., Rossvoll, F., Wallace, B., \& Daniel, B. (2010). 'It's just like another home, just another family, so it's nae different'. Children's voices in kinship care: a research study about the experience of children in kinship care in Scotland. Child \& Family Social Work, 15(3), 297306. doi:10.1111/j.1365-2206.2009.00671.x 
Chamberlain, P., Price, J. M., Reid, J. B., Landsverk, J., Fisher, P. A., \& Stoolmiller, M. (2006). Who disrupts from placement in foster and kinship care? Child abuse \& neglect, 30(4), 409-424.

Chambers, D. (2012). A sociology of family life. Cambridge, England: Polity press.

Cheal, D. (2002). Sociology of family life. London, England: Palgrave Macmillan.

Cuddeback, G. S. (2004). Kinship family foster care: A methodological and substantive synthesis of research. Children and Youth Services Review, 26(7), 623-639. doi:10.1016/j.childyouth.2004.01.014

Dubowitz, H. (1994). Kinship care: Suggestions for future research. Child Welfare, 73(5), 553-564.

Egelund, T. (1997). Beskyttelse af barndommen. Socialforvaltningers risikovurdering og indgreb. [The Protection of Childhood. Risk Assessment and Intervention of Child Protection Services ]. Copenhagen, Denmark: Hans Reitzels Forlag.

Egelund, T., Jakobsen, T. B., \& Steen, L. (2010). 'Det er jo min familie!' Beretninger fra børn og unge $i$ slagtspleje ['But it's my family!' Stories from children and youth in kinship care]. (Report no. 10:34). Copenhagen, Denmark: SFI.

Flynn, R. (2002). Research Review: Kinship foster care Child \& Family Social Work, 7(4), 311-321.

Font, S. A. (2014). Kinship and nonrelative foster care: The effect of placement type on child wellbeing. Child Development, 85(5), 2074-2090. doi:10.1111/cdev.12241

Font, S. A. (2015). Is higher placement stability in kinship foster care by virtue or design? Child abuse \& neglect, 42, 99-111. doi:10.1111/cdev.12241

Frost, N. (2002). A problematic relationship? Evidence and practice in the workplace. Social Work \& Social Sciences Review, 10(1), 38-50.

Gibbs, P., \& Müller, U. (2000). Kinship foster care moving to the mainstream: Controversy, policy, and outcomes. Adoption Quarterly, 4(2), 57-87. doi:10.1300/J145v04n02_04

Giddens, A. (1992). The Transformation of Intimacy: Sexuality, Love and Eroticism in Modern Societies. Cambridge, England: Polity press.

Gleeson, J. P., \& Hairston, C. F. (Eds.). (1999). Kinship care: Improving practice through research. Washington, DC CWLA Press.

Gray, M., Plath, D., \& Webb, S. A. (2009). Evidence-based social work: A critical stance. New York, NY: Routledge.

Guba, E. G. (1990). The paradigm dialog. Newbury Park, CA: Sage.

Gullestad, M., \& Segalen, M. (Eds.). (1997). Family and kinship in Europe. London: Pinter

Havik, T., \& Backe-Hansen, E. (1998). Kunnskapsstatus for fosterhjemsarbeidet. [A status of knowledge for foster care practice ]. Bergen: NOVA.

Hessle, S., \& Vinnerljung, B. (1999). Child Welfare in Sweden - An overview. Stockholm studies in social work. (Vol. 15). Stockholm, Sweden: Stockholm University, Institute of social work.

Holtan, A. (2008). Family types and social integration in kinship foster care. Children and Youth Services Review, 30(9), 1022-1036. doi:10.1016/j.childyouth.2008.01.002 
Iglehart, A. P. (1994). Kinship foster care: Placement, service, and outcome issues. Children and Youth Services Review, 16(1), 107-122.

Kiraly, M., \& Humphreys, C. (2013). Family contact for children in kinship care: A literature review. Australian Social Work, 66(3), 358-374.

Knudsen, L., \& Egelund, T. (2011). Effekter af slægtspleje: slægtsanbragte børn og unges udvikling sammenlignet med plejebørn fra traditionelle plejefamilier. [Effects of kinship care: children and youths development in kinship care comapred to non-kinship care ]. (Report nr. 11:20). Copenhagen, Denmark: SFI.

Linderot, S. (2006). Att placera eller inte placera i släktinghem, det är frågan. En studie kring familjehemsplaceringar- lagstiftning, attityder och handläggning inom socialtjänsten. [To place or not to place in kinship care, that is the question: A study of foster care placementslegislation, attitudes and administration within the social service ]. (Doctoral Dissertation). Lund, Sweden: Lund University, Department of Social Work.

McCarthy, J. R., \& Edwards, R. (2011). Key concepts in family studies. London, England: Sage.

Morgan, D. (1996). Family connections: An introduction to family studies. Cambridge, England: Polity press.

Morgan, D. (2011). Rethinking family practices. Hampshire, England: Palgrave Macmillan.

Nixon, P. (2007). Relatively Speaking: Developments in research and practice in kinship care. Dartington, England: Research in practice.

O'Brien, V. (2012). The Benefits and Challenges of Kinship Care. Child Care in Practice, 18(2), 127146. doi:10.1080/13575279.2012.657610

Parsons, T., \& Bales, R. F. (1955). Family: Socialization and interaction process. Glencoe, IL: The Free Press.

Pease, B. (2010). Challenging the dominant paradigm: Social work research, social justice and social change. In I. Shaw, K. Briar-Lawson, J. Orme, \& R. Ruckdeschel (Eds.). The Sage handbook of social work research (pp. 98-112). London, England: Sage Publications.

Pierce, W. L. (1999). Kinship care. In national council for adoption. In C. Marshner \& W. L. Pierce (Eds.). Adoption factbook III (pp. 104-116). Waite Park, MN: Park Press Quality Printing

Pitcher, D. (1999). When Grandparents Care. Plymouth, England: Plymouth City Council Services Department.

Sinclair, I., Baker, C., Lee, J., \& Gibbs, I. (2007). The pursuit of permanence: A study of the English care system. London, England: Jessica Kingsley Publishers.

Smart, C. (2007). Personal life. Cambridge, England: Polity press.

Smart, C., \& Neale, B. (1999). Family Fragments? Cambridge, England: Routledge.

Staunæs, D., \& Søndergaard, D. M. (2005). Interview i en tangotid. In M. Järvinen \& N. Mik-Meyer (Eds.). Kvalitative metoder i et interaktionistisk perspektiv. Copenhagen: Hans Reitzel.

Thørnblad, R. (2009). Slektsfosterhjem i offentlig barnevern. [Kinship care in child protective services]. Tidsskriftet Norges barnevern, 86(04), 221-235. 
Thørnblad, R., \& Holtan, A. (2011a). Kinship foster children: Actors in their encounter with the child protection system. Qualitative Social Work, 12(3), 307-322. doi:10.1177/1473325011428187

Thørnblad, R., \& Holtan, A. (2011b). Oppvekst i slektsfosterhjem: unge voksne fosterbarns familieforståelser. [Growing up in kinship foster care: the family understanding of young adult foster children]. Tidsskrift for ungdomsforskning, 11(1), 49-67.

Ulvik, O. S. (2009). Kunnskap for et seinmoderne barnevern: Forholdet mellom forskning og praksis [Knowledge for child welfare in late modern society: The relationship between research and practice ]. Tidsskrift for Norges Barnevern, 86(1), 18-27.

Weeks, J., Heaphy, B., \& Donovan, C. (2001). Same sex intimacies: Families of choice and other life experiments. London, England: Routledge

Williams, F. (2004). Rethinking Families London, England: Calouste Gulbenkian Foundation

Winokur, M., Holtan, A., \& Batchelder, K. E. (2014). Kinship care for the safety, permanency, and well-being of children removed from the home for maltreatment. Cochrane Database of Systematic Reviews 2014(1). doi:10.1002/14651858.pub3.

Wu, Q., White, K. R., \& Coleman, K. L. (2015). Effects of kinship care on behavioral problems by child age: A propensity score analysis. Children and Youth Services Review, 57, 1-8. doi:10.1016/j.childyouth.2015.07.020 